\title{
Analysing Spanish Learners' Beliefs about EFL Learning
}

\author{
Juan de Dios Martínez Agudo \\ University of Extremadura
}

Received: 19 January 2013 / Accepted: 22 February 2013

ISSN: $1697-7467$

\begin{abstract}
With the hope that research into learner beliefs will enrich our understanding of how learners actually approach and discover a new language, this paper aims to find out what Spanish learners actually believe and expect from their English classes, whether or not they are satisfied with the progress made and the English education received so far. The results suggest that the beliefs learners hold about EFL learning are largely induced by their past classroom learning experiences. Additionally, this study found evidence of unsatisfied learning expectations which may have a negative effect on classroom instruction and, thus, ultimate learning outcomes.
\end{abstract}

Keywords: learner beliefs, classroom learning experiences.

Análisis de las creencias de los estudiantes españoles sobre el aprendizaje del inglés como lengua extranjera

RESUMEN: Con la esperanza de que la investigación sobre las creencias de los estudiantes enriquezca nuestra comprensión acerca de cómo los estudiantes se aproximan o descubren realmente una nueva lengua, este trabajo pretende descubrir lo que los estudiantes españoles realmente creen y esperan de sus clases de inglés, si están o no satisfechos con el progreso realizado y con la enseñanza de inglés recibida. Los resultados sugieren que las creencias que los estudiantes tienen sobre el aprendizaje del inglés como lengua extranjera están en gran medida inducidas por sus pasadas experiencias de aprendizaje de aula. Además, este estudio halló evidencia de expectativas de aprendizaje insatisfechas las cuales pueden tener un efecto negativo sobre la instrucción de aula y, consecuentemente, sobre los resultados finales de aprendizaje.

Palabras clave: creencias del estudiante, experiencias de aprendizaje de aula.

\section{Literature ReView}

Throughout the last decades research interest in SLA has shifted from teacher-directed instruction to student-centered learning or rather the move away from teacher-centred classrooms towards a learner-centred approach has shifted the focus of research in language learning and teaching towards the learner as an individual. Learning individuality deserves special emphasis as Benson (2005:5) reminds us "learners are individuals and that their individuality may have significant consequences for their learning". In this sense, numerous studies have been conducted from the learner's perspective which reflects the 'subjective reality', the 'truth' from the learners' viewpoint (Riley, 1997). Since the mid 1980s, the 
role that learner beliefs play in second language learning has been attracting considerable research interest in Applied Linguistics. Elaine Horwitz's pioneering study (1987) generated considerable research interest in the nature of beliefs held by language learners. Since then, a multitude of research studies into the subject has been conducted in different SL/FL learning contexts (Park, 1995; Riley, 1997; Banya and Cheng, 1997; Gaies, 1998; Wenden, 1999; Sakui and Gaies, 1999; Mori, 1999; Horwitz, 1999; Benson and Lor, 1999; Yang, 1999; White, 1999; Breen, 2001; Alanen, 2003; Ferreira, 2003; Dufva, 2003; Kramsch, 2003; Kalaja, 2003; Kalaja and Ferreira, 2003; Williams et al., 2004; Dörnyei, 2005, 2006; Bernat and Gvozdenko, 2005; Bernat, 2004, 2005, 2006; Gabillon, 2005; Benson and Nunan, 2005; Nikitina and Furuoka, 2007; Ellis, 2008; Loewen et al., 2009; Pazaver and Wang, 2009; Ferreira and Kalaja, 2011; Mohammad and Shokrpour, 2012; Ghabanchi and Meidani, 2012; Saleh, 2012; Maftoon and Shakouri, 2013; Yoshida, 2013; Akbari and Karimi, 2013).

Learner beliefs have been of a great interest for many scholars from diverse disciplines. The issue of learners' beliefs, influenced by different theories and conceptualizations, has been mainly examined from cognitive psychology but also from a socio-cultural perspective. While cognitive research into learner beliefs recognised the individuality of human cognition (Williams and Burden, 1997), research into learner beliefs from a sociocultural perspective, in contrast, stressed the social nature of beliefs which are context-dependent, that is, constructed in a social context (Chawhan and Oliver, 2000; Kim-Yoon, 2000; Woods, 2003; Alanen, 2003; Dufva, 2003). To what extent beliefs are mental and individual but also social and cultural has been the major debate in the research literature. These days, many scholars actually support the dual nature of beliefs (Alanen, 2003; Dufva 2003).

Although learner 'beliefs' constitute an individual difference variable notably different from the other individual difference factors (Ellis, 2008) as Dörnyei (2005:214) claimed "presents us with a real dilemma in that it does not seem to be a proper ID variable because it is difficult to conceive beliefs as an enduring, trait-like factor", the fact is that 'beliefs', like other individual difference variables such as language aptitude and motivation, influence both the process and product of language learning (Ellis, 2008).

Generally, learner beliefs -or personal 'opinions' or pre-conceived ideas- are described as an important individual difference variable in L2 learning which "form the basis for our personal decisions as to how to proceed" (McDonough, 1995:9) and, accordingly, these predispositions to action may somehow account for learning progress and ultimate achievement (Breen, 2001; Dörnyei, 2005; Ellis, 2008). According to Victori and Lockhart (1995:224), learner beliefs can be defined as "general assumptions that students hold about themselves as learners, about factors influencing language learning, and about the nature of language learning and teaching" (Victori and Lockhart, 1995:224). More specifically, Alexander and Dochy (1995) argued that beliefs are viewed as idiosyncratic and subjective. In this sense, Gaies (1998) proposes three characteristics of beliefs about language learning: 1) beliefs are subjective understandings; 2) beliefs are relatively stable over time and 3) beliefs are idiosyncratic, that is, belief systems are unique to individuals. Additionally, learner beliefs are both dynamic and situation specific, that is, beliefs change over time as a product of new situational experiences (Sakui and Gaies, 1999; Ellis 2002, 2008; Tanaka, 2004; Zhong, 2008).

The origins of learning beliefs have been assumed to be acquired consciously as well as unconsciously (Larsen-Freeman, 2001). Learners hold common and, in some cases, er- 
roneous beliefs about how an L2 should best be learnt and taught in the classroom context, some of which are influenced by their previous classroom experiences, and others are shaped by their personality and their own cultural backgrounds which shape their attitudes towards language learning. Generally, learning outcomes seem to be greatly influenced by beliefs and attitudes (Arnold and Brown, 1999). Given the complex and multidimensional nature of learner beliefs, research evidence points to the conclusion that the preconceived ideas L2 learners indeed hold may not only influence the way they approach L2 learning but also affect the way they respond to particular teaching methods and classroom activities (Kuntz, 1996; Horwitz, 1999; Benson and Lor, 1999). Likewise, beliefs can influence learners' motivation, their expectations about language learning, their perceptions about what is easy or difficult, and the strategies they choose in learning (Richards and Lockhart, 1994). What learners actually bring to the language classroom -a complex set of perceptions, beliefs, attitudes, assumptions, interpretations, experiences, expectations and learning strategies- thus deserves special emphasis (Benson, 2001; Breen, 2001).

While the main emphasis in research is laid on the identification and description of learners' beliefs (based on responses to questionnaires), Ellis (2008) reminds us that very few research studies support the relationship between learner beliefs and learning outcomes (Park, 1995; Mori, 1999). While research evidence points to the conclusion that beliefs might affect learning outcomes (Park, 1995; Mori, 1999; Tanaka and Ellis, 2003), the fact is that these studies do not show a strong relationship between beliefs and learning outcomes. In fact, Ellis (2008) considers that if beliefs do impact on learning it is likely that they do so indirectly by influencing the kinds of learning strategies learners employ when discovering a new language.

To gain a better understanding of learner beliefs and their role in SLA, researchers have investigated diverse variables associated with these beliefs. The complexity and abundance of variables influencing L2 learners' beliefs makes this area difficult for researchers (Gabillon, 2005). So far, research into learner beliefs about language learning has provided us with valuable insights that may have important implications for L2 teaching, even though other important factors have been overlooked. One of the research areas of current interest lies in the factors that affect beliefs (e.g., individual learner differences (Siebert, 2003; Bernat, 2006) and contextual diversity (Rifkin, 2000; Kalaja and Ferreira, 2003). Specifically, recent research studies have examined learners' beliefs for their relationship to factors such as strategy use (White 1999; Horwitz, 1999; Sakui and Gaies, 1999; Yang, 1999; Ghabanchi and Meidani, 2012; Maftoon and Shakouri, 2013); anxiety (Banya and Chen, 1997; Kunt, 1998); motivation (Banya and Chen, 1997; Kim-Yoon, 2000); learner autonomy (Cotterall, 1995; Zhong, 2010); attitude (Riley, 1997; Banya and Cheng, 1997); achievement (Banya and Cheng, 1997); gender (Siebert, 2003), personality traits (Bernat, 2006); and language proficiency (Mantle-Bromley, 1995; Peackock, 1999; Tanaka and Ellis, 2003; Huang and Tsai, 2003; Akbari and Karimi, 2013).

L2 teachers should become aware of their students' past classroom experiences and pay close attention to their beliefs about language learning by considering what they actually expect from their language classes so as to better understand how they actually approach or face the new language (Benson and Lor, 1999). In this sense, teachers' understanding of learner beliefs would somehow contribute to more successful language learning (Cotterall, 1995; Yang, 1999; Chawhan and Oliver, 2000; Kim-Yoon, 2000). In addition, teachers should 
bear in mind that what they actually do inside the classroom might significantly influence their students' beliefs and attitudes towards the new language (Mori, 1999). Likewise, learners need to be aware of their own beliefs by verbalising them and assessing how these may affect their second language learning (Kalaja, 2003). Thus, assessing L2 learners' beliefs is essential to understanding their approaches to language learning (Riley, 1997; Horwitz, 1999; Benson and Lor, 1999; Sakui and Gaies, 1999; Yang, 1999; Wenden, 1999; Breen, 2001; Tanaka and Ellis, 2003). In this respect, Dörnyei (2001) reminds us of the importance of creating realistic learner beliefs as an important motivational strategy. According to Ellis (2008:24),

If beliefs influence the actions that learners perform to learn an L2, they cannot be ignored by teachers. Little learning is likely if there is a mismatch between the teacher's and the students' belief systems. This suggests the need for teachers to make their own beliefs about language learning explicit, to find out about their students' beliefs, to help their students become aware of and to evaluate their own beliefs and to address any mismatch in their and their students' belief systems.

Although learner beliefs are actually viewed as an important individual difference variable in L2 learning (Dörnyei, 2005; Ellis, 2008), the fact is that learner beliefs about language learning have remained relatively unexplored, especially with those who will become teachers of the languages they have been learning. As indicated above, research into learner beliefs will enrich our understanding of SLA. Accordingly, we need to discover what students actually expect from language classes and believe about their learning so as to account for how they actually approach and face second language learning. So far research into learner beliefs about language learning has provided us with valuable insights. What is not clear yet is how and to what extent learners' beliefs actually impact on L2 learning. Thus, more research is needed in this area to fully understand the real impact of learner beliefs on L2 learning.

\section{RESEARCH QUESTIONS}

Drawing on the results of the research to date, the present study focused on the following research questions:

- What beliefs do Spanish learners hold about EFL learning?

- To what extent does the way Spanish students learned English affect their beliefs and perceptions about EFL learning?

- Do learners feel satisfied with the progress made and the English education received by bearing in mind their past classroom learning experiences?

\section{Method}

In SLA research, individual learner differences have traditionally been measured statistically within a quantitative research framework. Regarding research methodology, several research paradigms or methods have been employed by investigators such as questionnaires, 
interviews and focus group discussions (see Ferreira (2003) for a review). In order to examine learner beliefs, most research studies employ some kind of self-report as data collection instrument such as Likert-scale questionnaires or interviews where learners self-report their beliefs. It also needs to be remembered that the normative approach is mainly characterized by the use of Likert-scale questionnaires to which learners indicate their degree of agreement or disagreement with several statements. However, Victori (1999) points out several methodological problems and limitations of questionnaires such as the wording of the questions asked, types of questions asked, failure to provide in-depth analysis of each response, among many others, even though she concludes that the choice of instruments mainly depends on the researcher's purpose and on the amount of data to be collected. While questionnaires seem adequate to quantify data and to "provide descriptions and comparisons of learner beliefs", semi-open oral interviews seem most appropriate for qualitative information (Victori, 1999: 16). As Ellis (2008) reminds us, the choice of research methodology in learner beliefs studies will mainly depend on the investigator's purpose and questions of enquiry, as well as the adopted view of the nature and function of learner beliefs.

\subsection{Participants}

Learning at least one foreign language is compulsory in almost all primary and secondary schools of Europe. The research presented in this paper was carried out in schools located in Extremadura, an autonomous region of western Spain, on the border with Portugal. We collected data from two secondary education schools which were randomly selected, particularly four classes from each school. A total of 218 Spanish secondary school students participated in the investigation voluntarily. The researcher discarded 7 invalid questionnaires which were either incomplete or failed to follow the instructions of the questionnaire, resulting in a sample of 211 out of the original sample of 218. Accordingly, the valid response rate was $96.78 \%$ and a total of 211 questionnaires were identified as valid data for statistical analysis in the present study. A sample of 211 Spanish secondary school learners was eventually employed, of these $93(44.07 \%)$ were males and $118(55.92 \%)$ were females. Of the 211 students selected $115(54.50 \%)$ were in the first year of Bachillerato and $96(45.49 \%)$ were in the second year. Their average age was 17, ranging from sixteen to nineteen. Additionally, the participants in the survey had studied English for twelve years on average. The average classroom level was upper intermediate. The vast majority of the students $(82 \%)$ had never visited an English-speaking country, and only a small minority (18\%) had spent some time (a few weeks) on holidays in either Great Britain or the USA.

\subsection{Data collection instrument and procedure}

While learner beliefs about language learning have traditionally been measured by Horwitz's (1987) BALLI (Beliefs About Language Learning Inventory), used as a reliable research tool by many researchers, other Likert-scale questionnaires were also designed and used for investigating learners' beliefs (e.g. Kuntz, 1996; Cotterall, 1999; Sakui and Gaies, 1999). The instrument employed in this study is the questionnaire developed by Sakui and Gaies (1999) which uses a combination of original items and others from previous questionnaires, mainly Horwitz's BALLI. Sakui and Gaies's wide scale study (1999) of almost 1300 
Japanese university students of English is very insightful. This 45 -statement questionnaire employs a 5-point Likert-scale ranging from strongly disagree to strongly agree.

The Sakui-Gaies belief questionnaire was administered to students during class time and they were able to complete the instrument in less than 15 minutes. The students' individual responses to each item on the questionnaire were then entered into a database. Descriptive analysis in the form of percentages was then computed.

\subsection{Analysis and discussion of results}

This research paper adopts the same approach to data analysis from Horwitz's studies as we used only descriptive statistics. Quantitative data from the questionnaire were only utilized for descriptive statistics to answer the aforementioned research questions. Table 1 displays the results with agreement percentages.

Table 1. Summary of descriptive statistics.

\begin{tabular}{|c|c|c|c|c|c|}
\hline $\begin{array}{l}\text { STRONGLY } \\
\text { DISAGREE }\end{array}$ & DISAGREE & $\begin{array}{c}\text { NEITHER } \\
\text { AGREE } \\
\text { NOR } \\
\text { DISAGREE }\end{array}$ & AGREE & $\begin{array}{c}\text { STRONGLY } \\
\text { AGREE }\end{array}$ & TOTAL \\
\hline \multicolumn{6}{|c|}{ Statement 1 . The English conversation class should be enjoyable. } \\
\hline $0.58 \%$ & $3.51 \%$ & $14.62 \%$ & $50.29 \%$ & $30.99 \%$ & $100.00 \%$ \\
\hline \multicolumn{6}{|c|}{ Statement 2. In learning English it is important to repeat and practise a lot. } \\
\hline $0.00 \%$ & $2.34 \%$ & $12.28 \%$ & $44.44 \%$ & $40.94 \%$ & $100.00 \%$ \\
\hline \multicolumn{6}{|c|}{$\begin{array}{l}\text { Statement 3. Listening to tapes and watching English programs on television are very important in } \\
\text { learning English. }\end{array}$} \\
\hline $1.75 \%$ & $4.68 \%$ & $23.39 \%$ & $40.94 \%$ & $29.24 \%$ & $100.00 \%$ \\
\hline \multicolumn{6}{|c|}{ Statement 4 . I should be able to learn everything I am taught. } \\
\hline $1.75 \%$ & $10.53 \%$ & $35.67 \%$ & $35.67 \%$ & $16.37 \%$ & $100.00 \%$ \\
\hline \multicolumn{6}{|c|}{ Statement 5. It is useful to know about English-speaking countries in order to speak English. } \\
\hline $7.02 \%$ & $18.13 \%$ & $36.26 \%$ & $26.90 \%$ & $11.70 \%$ & $100.00 \%$ \\
\hline \multicolumn{6}{|c|}{ Statement 6. It is easier for children than adults to learn English. } \\
\hline $4.09 \%$ & $5.26 \%$ & $18.71 \%$ & $33.92 \%$ & $38.01 \%$ & $100.00 \%$ \\
\hline \multicolumn{6}{|c|}{ Statement 7. Speaking and listening to English are more useful than reading and writing English. } \\
\hline $4.09 \%$ & $19.88 \%$ & $28.65 \%$ & $26.90 \%$ & $20.47 \%$ & $100.00 \%$ \\
\hline
\end{tabular}




\begin{tabular}{|c|c|c|c|c|c|}
\hline \multicolumn{7}{|c|}{ Statement 8. Some languages are easier to learn than others. } \\
\hline $1.75 \%$ & $2.92 \%$ & $10.53 \%$ & $34.50 \%$ & $50.29 \%$ & $100.00 \%$ \\
\hline
\end{tabular}

Statement 9. If I learn to speak English very well, I will have many opportunities to use it.

\begin{tabular}{|l|l|l|l|l|l|}
$2.92 \%$ & $2.92 \%$ & $5.85 \%$ & $30.99 \%$ & $57.31 \%$ & $100.00 \%$ \\
\hline
\end{tabular}

Statement 10. I am studying (studied) English only to pass the final examination.

\begin{tabular}{|l|c|c|c|c|c|}
$32.75 \%$ & $30.99 \%$ & $14.62 \%$ & $12.87 \%$ & $8.77 \%$ & $100.00 \%$ \\
\hline
\end{tabular}

Statement 11. If I learn to speak English very well, it will help me get a good job.

\begin{tabular}{|c|c|c|c|c|c|}
\hline $1.75 \%$ & $2.92 \%$ & $8.19 \%$ & $35.67 \%$ & $51.46 \%$ & $100.00 \%$ \\
\hline \multicolumn{6}{|c|}{ Statement 12. It is OK to guess if you do not know a word in English. } \\
\hline $3.51 \%$ & $7.02 \%$ & $33.92 \%$ & $41.52 \%$ & $14.04 \%$ & $100.00 \%$ \\
\hline
\end{tabular}

Statement 13. If my teacher is a native speaker, he/she should be able to speak Spanish when necessary.

\begin{tabular}{|l|l|l|l|l|l|}
\hline $6.43 \%$ & $12.28 \%$ & $21.05 \%$ & $30.99 \%$ & $29.24 \%$ & $100.00 \%$ \\
\hline
\end{tabular}

Statement 14. I study English because it is useful to communicate with English-speaking people.

\begin{tabular}{|c|c|c|c|c|c|}
\hline $4.68 \%$ & $12.87 \%$ & $26.32 \%$ & $36.26 \%$ & $19.88 \%$ & $100.00 \%$ \\
\hline \multicolumn{6}{|c|}{ Statement 15. Spaniards think it is important to speak English. } \\
\hline $7.60 \%$ & $5.85 \%$ & $32.16 \%$ & $35.67 \%$ & $18.71 \%$ & $100.00 \%$ \\
\hline
\end{tabular}

Statement 16. I would feel embarrassed to speak English in front of other Spanish students.

\begin{tabular}{|l|c|c|c|c|c|}
\hline $16.37 \%$ & $17.54 \%$ & $32.16 \%$ & $25.15 \%$ & $8.77 \%$ & $100.00 \%$ \\
\hline
\end{tabular}

Statement 17. To say something in English, I think of how I would say it in Spanish and then translate it into English.

\begin{tabular}{|l|c|c|c|c|c|}
\hline $11.70 \%$ & $15.79 \%$ & $23.39 \%$ & $25.73 \%$ & $23.39 \%$ & $100.00 \%$ \\
\hline
\end{tabular}

Statement 18. I can improve my English by speaking English with my classmates.

\begin{tabular}{|c|c|c|c|c|c|}
\hline $3.51 \%$ & $12.87 \%$ & $26.32 \%$ & $38.60 \%$ & $18.71 \%$ & $100.00 \%$ \\
\hline \multicolumn{6}{|c|}{ Statement 19. Learning English is different from learning other subjects. } \\
\hline $1.75 \%$ & $5.26 \%$ & $17.54 \%$ & $47.37 \%$ & $28.07 \%$ & $100.00 \%$ \\
\hline Statement 20. In English classes, I prefer to have my teacher provide explanations in Spanish. \\
\hline $20.47 \%$ & $13.45 \%$ & $23.39 \%$ & $21.05 \%$ & $21.64 \%$ & $100.00 \%$ \\
\hline \multicolumn{7}{|c|}{ Statement 21. It is easier to read and write English than to speak and understand it. } \\
\hline $8.77 \%$ & $16.96 \%$ & $26.32 \%$ & $24.56 \%$ & $23.39 \%$ & $100.00 \%$ \\
\hline
\end{tabular}




\begin{tabular}{|c|c|c|c|c|c|}
\hline \multicolumn{6}{|c|}{ Statement 22. Some people are born with a special ability which is useful for learning English. } \\
\hline $15.20 \%$ & $12.87 \%$ & $23.98 \%$ & $29.24 \%$ & $18.71 \%$ & $100.00 \%$ \\
\hline \multicolumn{6}{|c|}{ Statement 23. I make mistakes because I do not study enough. } \\
\hline $5.85 \%$ & $23.98 \%$ & $22.22 \%$ & $33.92 \%$ & $14.04 \%$ & $100.00 \%$ \\
\hline \multicolumn{6}{|c|}{$\begin{array}{l}\text { Statement 24. If you are allowed to make mistakes in the beginning, } \\
\text { it will be hard to get rid of them later on. }\end{array}$} \\
\hline $1.17 \%$ & $10.53 \%$ & $28.65 \%$ & $29.82 \%$ & $29.82 \%$ & $100.00 \%$ \\
\hline \multicolumn{6}{|c|}{ Statement 25 . The longer I study English, the more enjoyable I find it. } \\
\hline $9.94 \%$ & $13.45 \%$ & $40.35 \%$ & $23.39 \%$ & $12.87 \%$ & $100.00 \%$ \\
\hline \multicolumn{6}{|c|}{ Statement 26. It is easier for someone who already speaks a foreign language to learn another one. } \\
\hline $5.26 \%$ & $11.70 \%$ & $38.60 \%$ & $29.82 \%$ & $14.62 \%$ & $100.00 \%$ \\
\hline \multicolumn{6}{|c|}{ Statement 27. I want my teacher to correct all my mistakes. } \\
\hline $4.68 \%$ & $7.02 \%$ & $16.96 \%$ & $37.43 \%$ & $33.92 \%$ & $100.00 \%$ \\
\hline \multicolumn{6}{|c|}{$\begin{array}{l}\text { Statement 28. If I heard a foreigner of my age speaking English, } \\
\text { I would go up to that person to practice speaking. }\end{array}$} \\
\hline $14.62 \%$ & $17.54 \%$ & $29.24 \%$ & $25.15 \%$ & $13.45 \%$ & $100.00 \%$ \\
\hline \multicolumn{6}{|c|}{ Statement 29. People who speak more than one language well are very intelligent. } \\
\hline $7.02 \%$ & $18.13 \%$ & $38.60 \%$ & $26.90 \%$ & $9.36 \%$ & $100.00 \%$ \\
\hline \multicolumn{6}{|c|}{ Statement 30. It is easier to speak English than to understand it. } \\
\hline $10.53 \%$ & $23.39 \%$ & $32.16 \%$ & $26.90 \%$ & $7.02 \%$ & $100.00 \%$ \\
\hline \multicolumn{6}{|c|}{ Statement 31. Learning a word means learning the Spanish translation. } \\
\hline $12.28 \%$ & $17.54 \%$ & $30.41 \%$ & $29.82 \%$ & $9.94 \%$ & $100.00 \%$ \\
\hline \multicolumn{6}{|c|}{ Statement 32. To understand English, it must be translated into Spanish. } \\
\hline $14.04 \%$ & $21.05 \%$ & $23.39 \%$ & $28.65 \%$ & $12.87 \%$ & $100.00 \%$ \\
\hline \multicolumn{6}{|c|}{$\begin{array}{l}\text { Statement 33. If a person studies English by himself for } 1 \text { hour a day, } \\
\text { he will be fluent in English in } 5 \text { years. }\end{array}$} \\
\hline $11.11 \%$ & $20.47 \%$ & $45.61 \%$ & $15.20 \%$ & $7.60 \%$ & $100.00 \%$ \\
\hline \multicolumn{6}{|c|}{ Statement 34. I believe that someday I will speak English very well. } \\
\hline $4.68 \%$ & $4.68 \%$ & $22.22 \%$ & $36.26 \%$ & $32.16 \%$ & $100.00 \%$ \\
\hline
\end{tabular}




\begin{tabular}{|c|c|c|c|c|c|}
\hline \multicolumn{6}{|c|}{ Statement 35 . Girls are better than boys at learning English. } \\
\hline $30.99 \%$ & $20.47 \%$ & $27.49 \%$ & $11.11 \%$ & $9.94 \%$ & $100.00 \%$ \\
\hline \multicolumn{6}{|c|}{ Statement 36. You can learn to improve your English only from native speakers of English. } \\
\hline $15.79 \%$ & $29.82 \%$ & $35.09 \%$ & $16.37 \%$ & $2.92 \%$ & $100.00 \%$ \\
\hline \multicolumn{6}{|c|}{ Statement 37 . Learning English is mostly a matter of learning grammar rules. } \\
\hline $4.09 \%$ & $25.15 \%$ & $39.18 \%$ & $23.39 \%$ & $8.19 \%$ & $100.00 \%$ \\
\hline \multicolumn{6}{|c|}{ Statement 38. Learning English is mostly a matter of translating from Spanish. } \\
\hline $14.62 \%$ & $26.32 \%$ & $42.11 \%$ & $12.28 \%$ & $4.68 \%$ & $100.00 \%$ \\
\hline \multicolumn{6}{|c|}{ Statement 39. I am satisfied with the English education I received. } \\
\hline $8.77 \%$ & $17.54 \%$ & $21.64 \%$ & $39.77 \%$ & $12.28 \%$ & $100.00 \%$ \\
\hline \multicolumn{6}{|c|}{ Statement 40 . People who are good at maths and science are not good at learning foreign languages } \\
\hline $45.61 \%$ & $28.65 \%$ & $16.96 \%$ & $7.02 \%$ & $1.75 \%$ & $100.00 \%$ \\
\hline \multicolumn{6}{|c|}{ Statement 41 . Spaniards are good at learning foreign languages. } \\
\hline $13.45 \%$ & $25.73 \%$ & $49.71 \%$ & $5.85 \%$ & $5.26 \%$ & $100.00 \%$ \\
\hline \multicolumn{6}{|c|}{$\begin{array}{c}\text { Statement } 42 . \text { In order to learn to read and write English very well, English education at school is } \\
\text { enough. }\end{array}$} \\
\hline $21.64 \%$ & $30.41 \%$ & $28.65 \%$ & $15.79 \%$ & $3.51 \%$ & $100.00 \%$ \\
\hline \multicolumn{6}{|c|}{$\begin{array}{l}\text { Statement 43. In order to speak and understand English very well, English education at school is } \\
\text { enough. }\end{array}$} \\
\hline $22.81 \%$ & $32.16 \%$ & $22.81 \%$ & $14.04 \%$ & $8.19 \%$ & $100.00 \%$ \\
\hline \multicolumn{6}{|c|}{$\begin{array}{l}\text { Statement 44. Considering the amount of time I have studied English, I am satisfied with my } \\
\text { progress. }\end{array}$} \\
\hline $9.94 \%$ & $16.37 \%$ & $28.07 \%$ & $31.58 \%$ & $14.04 \%$ & $100.00 \%$ \\
\hline \multicolumn{6}{|c|}{ Statement 45. You should not say anything in English until you can speak it correctly. } \\
\hline $36.26 \%$ & $34.50 \%$ & $19.30 \%$ & $7.60 \%$ & $2.34 \%$ & $100.00 \%$ \\
\hline
\end{tabular}

Note: Scores are based on a 1 to 5 scale in which 1 represents "strongly disagree" and 5 represents "strongly agree".

Table 1 reports the results obtained from learners' responses with percentages of students selecting each alternative. After the data-gathering process, the next step was to synthesise and analyse the results. As displayed in Figure 1, several statements generated very high levels of agreement ('strongly agree' and 'agree'). 


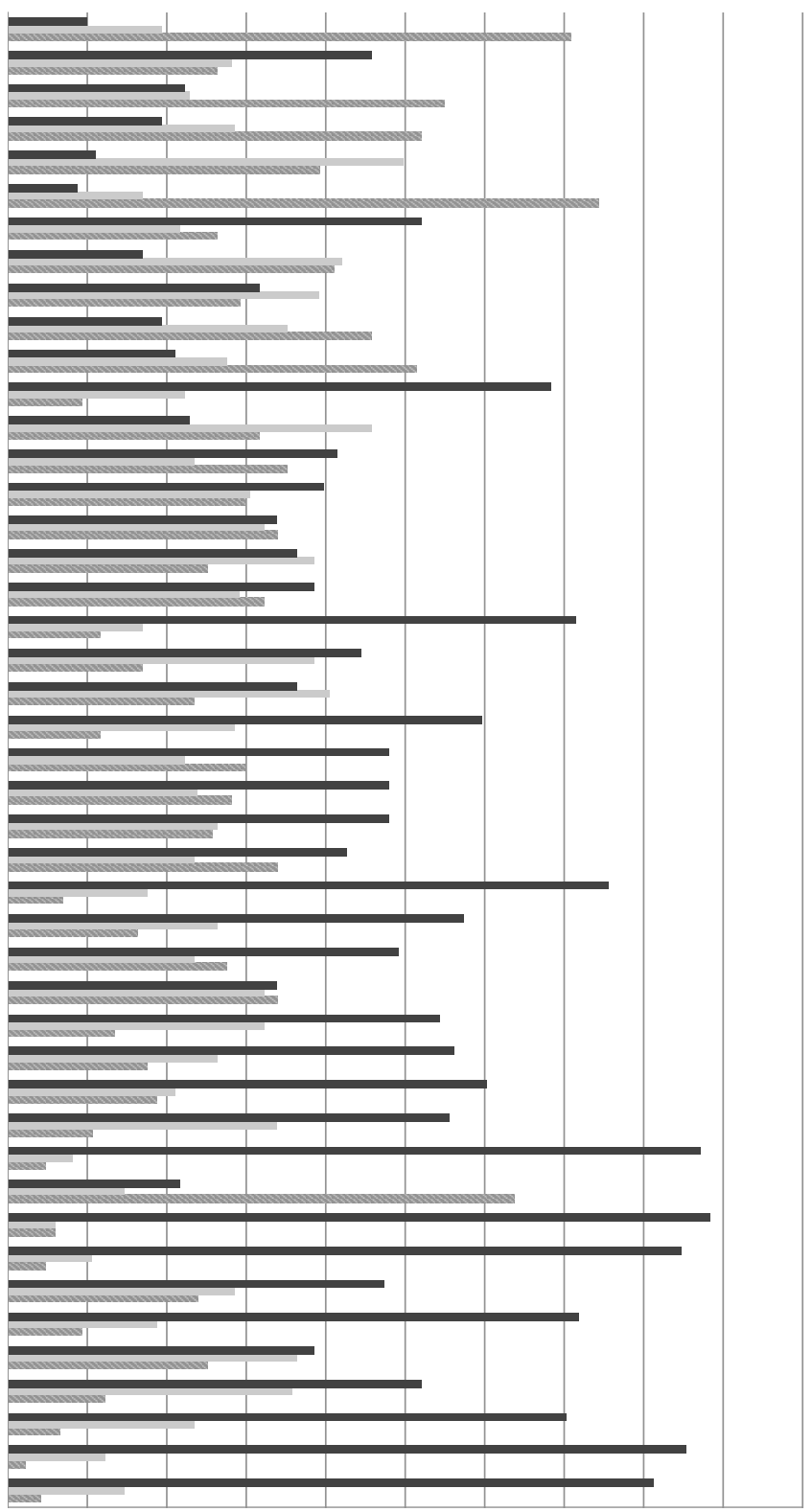

Figure 1. Descriptive statistics concerning learner beliefs about EFL learning. 
As can be seen from the data presented in Table 1 and illustrated in Figure 1, several statements generated very high levels of agreement ('strongly agree' and 'agree'). Only those statements which generated levels of agreement above $60 \%$ will be analysed below.

As reported in Table 1, the statement which obtained the highest percentage is statement $9(88.30 \%)$, followed by statement $11(87.13 \%)$, which both concern the instrumental value of learning English for communicative purposes. Both statements concern beliefs related to a communicative orientation to learning English. Rather, instrumental orientation seems to be the major driving force for learning English among the learners surveyed. Both statements are somehow related to students' attitudes towards English learning.

The next highest average was obtained from statement $2(85.38 \%)$ which assesses the importance of continued repetition and practice as important factors in English learning. Most participants believed that a great amount of repetition and intensive oral practice are essential for successful English learning. It is generally believed that learning a second language involves a lot of repetition and practice in order to assimilate the new language knowledge. There is no doubt that learning a foreign language is a task that requires a great deal of time, effort and dedication.

Statement 8 also received a high level of agreement (specifically, 84.79\%). Most subjects believed that some languages are easier to learn than others, even though maybe this may depend on how close these languages are to one's native language and on the complexity of their grammar and pronunciation. Rather, some languages are definitely easier to learn than others, especially those which share cultural and geographic origins and have linguistic similarities. Additionally, it is believed that it is easier for someone who already speaks a foreign language to learn another language.

In statement 1 we also noted high levels of agreement because most respondents (81.28\%) believed in the importance of enjoying the language learning experiences. It is somehow suggested that teachers need to constantly create pleasurable learning experiences in the language classroom. As Sakui and Gaies' (1999) study, most subjects agreed that 'The English conversation class should be enjoyable'. They felt that teachers should make English learning an enjoyable experience for their students which will make learning a second language much quicker and easier for them. Thus, the role of the affective domain in the FL classroom is particularly stressed here.

About three quarters of the participants (75.44\%) agreed that learning English is different from learning other subjects (statement 19). Likewise, the belief 'the earlier the start the better' (statement 6) received high levels of agreement. Specifically, more than two thirds of the respondents (71.93\%) expressed their agreement with the idea that it is easier for children to learn English than it is for adults.

Another area of concern is error treatment. We can see that most respondents (specifically $71.35 \%)$ preferred their teachers to correct every mistake they make when learning English (statement 27) and 59.64\% of students agreed that mistakes uncorrected in the beginning will be harder to attend to at a later stage (statement 24). Accordingly, the results somehow suggest that students expect to be constantly corrected by their teacher.

Concerning the importance of being constantly exposed to massive oral input in English (statement 3), 70.18\% of the participants agreed that listening to tapes and watching English programs on television are very important in learning English. The respondents found exposure to authentic and motivating aural practice through the use of appropriate listening activities and television programmes highly helpful. Likewise, statements 2 and 3 constitute beliefs relating to a communicative orientation to learning English. 
Statement 34 somehow provides evidence of an internal desire to use English for communicative purposes. In fact, more than two thirds of the respondents (specifically $68.42 \%$ ) hoped to communicate in English successfully. They believed that someday they would speak English very well.

Finally, statement 13 also received relatively high levels of agreement because $60.23 \%$ of the subjects agreed that even if their teachers are native English speakers, they should be able to speak Spanish when necessary. In fact, $42.69 \%$ of respondents reported a preference for those teachers who provide explanations in Spanish in English classes (statement 20). Regarding the over-dependence on strategies reliant on translation from the first language which is viewed as a serious obstacle in communication-focused classrooms, we can see from Table 1 that somewhat less than half of participants believed in the necessity of L1-L2 translation. Specifically, nearly half of respondents (49.12\%) agreed that before saying something in English they first need to think of how they would say it in Spanish and translate it into English (statement 17). Similar percentages can be found in both statements 31 and 32 . Namely, $39.76 \%$ of students agreed that learning a word means learning the Spanish translation (statement 31 ) and $41.52 \%$ of students agreed that to understand English, it must be translated into Spanish (statement 32). While at least only $16.96 \%$ of participants agreed with the idea that learning English is mostly a matter of translating from Spanish (statement 38), 42.11\% neither agreed nor disagreed. Certainly, the traditional Grammar-Translation method is still widely employed in Spain. An over-emphasis on grammar explanation and translation still prevails at least in the Spanish instructional settings. As regards the over-emphasis on grammar lessons, while nearly one third of subjects (specifically, $31.58 \%$ ) believed that learning English is mostly a matter of learning grammar rules (statement 37 ), $39.18 \%$ neither agreed nor disagreed. Certainly, all these beliefs are directly related to a traditional view of language learning.

Given the descriptive results, there are several similarities between the results of this study and those of Sakui and Gaies (1999). Table 2 compares the mean scores between the two studies for the five strongest reported beliefs.

Table 2. Comparison of 5 strongest reported beliefs with Sakui and Gaies (1999).

\begin{tabular}{|c|c|}
\hline $\begin{array}{l}\text { Strongest learner beliefs in } \\
\text { Sakui and Gaies (1999) } \\
\text { - in order of importance - }\end{array}$ & $\begin{array}{l}\text { The top five learners' beliefs } \\
\text { in this study } \\
\text { - in order of importance - }\end{array}$ \\
\hline $\begin{array}{l}\left(1^{\circ}\right) \text { St. } 1 . \text { The English conversation class should } \\
\text { be enjoyable }\end{array}$ & $\begin{array}{l}\left(1^{\circ}\right) \text { St. 9. If I learn to speak English very well, I } \\
\text { will have many opportunities to use it. }\end{array}$ \\
\hline $\begin{array}{l}\mathbf{2}^{\mathbf{o}} \text { - St. } 45 . \text { You should not say anything in } \\
\text { English until you can speak it correctly. }\end{array}$ & $\begin{array}{l}\left(\mathbf{2}^{\circ}\right) \text { St. 11. If I learn to speak English very well, } \\
\text { it will help me get a good job. }\end{array}$ \\
\hline $\begin{array}{l}\left(3^{\circ}\right) \text { St. 2. In learning English it is important to } \\
\text { repeat and practise a lot. }\end{array}$ & $\begin{array}{l}\left(3^{\circ}\right) \text { St. 2. In learning English it is important to } \\
\text { repeat and practise a lot. }\end{array}$ \\
\hline $\begin{array}{l}4^{\mathbf{0}}-\text { St. } 44 . \text { Considering the amount of time } \\
\text { I have studied English, I am satisfied with my } \\
\text { progress. }\end{array}$ & $\begin{array}{l}\left(4^{\circ}\right) \text { St. 8. Some languages are easier to learn } \\
\text { than others. }\end{array}$ \\
\hline $\begin{array}{l}\mathbf{5}^{\circ}-\text { St. } 43 . \text { In order to speak and understand } \\
\text { English very well, English education at school } \\
\text { is not enough. }\end{array}$ & $\begin{array}{l}\left(5^{\circ}\right) \text { St. 1. The English conversation class should } \\
\text { be enjoyable. }\end{array}$ \\
\hline
\end{tabular}


As displayed in Table 2, we can see that two of the five strongest items in this study also appeared in the strongest learner beliefs of Sakui and Gaies: statements 1 and 2.

\section{Conclusions}

Based on the results of descriptive statistics, the present study revealed that participants held, to varying degrees, a variety of fixed beliefs about EFL learning, which might somehow be shaped and induced by their past classroom learning experiences. Therefore, this study found evidence that the way students learned English affects in some way their beliefs and perceptions about EFL learning. Although the resulting data provided evidence of high expectations to use English for communicative purposes -communicative orientation-, the over-dependence on strategies reliant on translation from L1, which is viewed as a serious obstacle in communication-focused classrooms, was also found. Rather, the communicative orientation seems to receive special emphasis, even though the traditional view of language learning based on grammar-translation method still prevails to a certain extent. Additionally, the results somehow suggest that Spanish EFL learners are neither entirely satisfied with the English education received so far nor with the progress made which indicates that their English lessons are not actually satisfying their language learning needs. In fact, most respondents stressed the importance of creating enjoyable classroom experiences for successful English learning. This perception of slow progress (about half of respondents) in learning English which does not actually match their learning expectations may have a negative effect on classroom instruction and ultimate learning outcomes.

\section{Limitations AND FUtURE RESEARCH}

Several limitations in the research design make it difficult to make overall generalizations about the potential implications of this research study. Namely, the insufficient number of participants $(n=211)$ and the respondents' problems with understanding the meaning of the questionnaire items could be seen as the greatest limitations of the present research study. Given that the questionnaire was distributed to the students in English, the results from the scale should be interpreted with caution. As with any survey instrument, there is a chance that respondents may misunderstand certain questionnaire items due to either their own limited language proficiency or the subjective nature of a questionnaire item. Thus, caution should be exercised in generalizing the current findings beyond this student population, or indeed to other wider populations. Because of the very limited size of the sample, research findings call for replication on larger populations and in different teaching contexts. For future studies, a greater number of participants and the inclusion of more open-ended questions in the research instrument could be considered. Thus, special care should be taken in interpreting the results. This research article must be interpreted in the light of its limitations.

Learners' beliefs about language learning and teaching demand further exploration. So far, research, as Ferreira (2003:7) claimed, "has mainly described beliefs without trying to understand why students have certain beliefs and what role they play in students' learning experiences". In this sense, some researchers suggest the need for further studies on how beliefs differ across learners, 
particularly in terms of individual differences (Horwitz, 1999; Wenden, 1999; Rifkin, 2000; Bernat and Gvozdenko, 2005). So far, learner beliefs have been studied in a variety of cultural contexts, with different learner groups and target languages. Ellis (2008) also acknowledges the need to examine the extent to which learners act on their beliefs (i.e. the learning strategies that they employ). Likewise, as Bernat and Gvozdenko (2005:13) suggested, more research is actually needed in this area "to determine to what extent (if at all) can and should various classroom intervention methods be applied in order to bring about change in learner's beliefs about language learning". This is another area for future investigation.

\section{REFERENCES}

Akbari, R. and Karimi, M.N. (2013). "EFL students' proficiency outcomes: What do epistemological beliefs have to offer?", in The Asian EFL Journal, 15 (3): 1-17.

Alanen, R. (2003). "A sociocultural approach to young language learners' beliefs about language learning", in P. Kalaja and A.M. Ferreira (eds.), Beliefs about SLA: New Research Approaches. Netherlands: Kluwer Academic Publishers, 55-85.

Alexander, P.A. and Dochy, F. (1995). "Conceptions of knowledge and beliefs: A comparison across varying cultural and educational communities", in American Educational Research Journal, 32: 413-442.

Arnold, J. and Brown, H.D. (1999). "A map of the terrain”, in J. Arnold (ed.), Affect in Language Learning. Cambridge: Cambridge University Press, 1-24.

Banya, K. and Cheng, M. (1997). "Beliefs about language learning-A study of beliefs of teachers' and students' cultural settings". Paper presented at the Annual Meeting of the Teachers of English to Speakers of Other Languages (31st, Orlando, FL, March 11-15, 1997). ED 411691.

Benson, P. (2001). Teaching and Researching Autonomy in Language Learning. Harlow: Pearson Education Limited.

Benson, P. (2005). "(Auto)biography and learner diversity”, in P. Benson and D. Nunan (eds.), Learner's Stories: Difference and Diversity in Language Learning. Cambridge: Cambridge University Press, 4-21.

Benson, P. and Lor, W. (1999). "Conceptions of language and language learning", in System, 27(4): 459-472.

Benson, P. and Nunan, D. (eds.) (2005). Learners' Stories: Difference and Diversity in Language Learning. Cambridge: Cambridge University Press.

Bernat, E. (2004). "Investigating Vietnamese ESL learners' beliefs about language learning”, in EA Journal, 21(2): 40-54.

Bernat, E. (2006). “Assessing EAP Learners' Beliefs about Language Learning in the Australian Context", in Asian EFL Journal, 8, 2: 202-227.

Bernat, E. and Gvozdenko, I. (2005). "Beliefs about Language Learning: Current Knowledge, Pedagogical Implications, and New Research Directions", in TESL-EJ, 9(1): 1-21.

Breen, M.P. (ed.), (2001). Learner contributions to language learning: New directions in research. Harlow, Essex: Pearson Education Limited.

Chawhan, L. and Oliver, R. (2000). "What beliefs do ESL students hold about language learning?", in TESOL in Context, 10(1): 20-26.

Cotterall, L.S. (1999). "Key variables in language learning: what do learners believe about them?", in System, 27: 493-513. 
Cotterall, S. (1995). "Readiness for autonomy: Investigating learner beliefs", in System, 23: 195-205.

Dörnyei, Z. (2001). Teaching and Researching Motivation. England: Pearson Education Limited.

Dörnyei, Z. (2005). The Psychology of the Language Learner: Individual Differences in Second Language Acquisition. London: Routledge.

Dörnyei, Z. (2006). "Individual differences in second language acquisition", in AILA Review, 19: 42-68.

Dufva, H. (2003). "Beliefs in dialogue: A Bakhtinian view", in P. Kalaja and A.M. Ferreira (eds.), Beliefs about SLA: New Research Approaches. Netherlands: Kluwer Academic Publishers, 131-152.

Ellis, R. (2002). "A metaphorical analysis of learner beliefs", in P. Burmeister, T. Piske and A. Rohde (eds.), An Integrated View of Language Development: Papers in Honor of Henning Wode. Trier, Germany: Wissenschaftlicher Verlag, 163-179.

Ellis, R. (2008). "Learner beliefs and language learning", in Asian EFL Journal, 10, 4: 7-25.

Ferreira, A.M" (2003). "Researching beliefs about SLA: A critical review", in P. Kalaja and A. M ${ }^{\mathrm{a}}$ Ferreira (eds.), Beliefs about SLA. New Research Approaches. The Netherlands: Kluwer Academic Publishers, 7-33.

Ferreira, A.M a and Kalaja, P. (2011). "Introduction to Beliefs about SLA revisited", in System, 39 (3): 281-289.

Gabillon, Z. (2005). "L2 Learner's Beliefs: An Overview”, in Journal of Language and Learning, 3 (2): $233-260$.

Gaies, S. (1998). "Japanese language learners' perceptions of methodological alternatives". Presentation at the Japan Association for Language Teaching 1998 Conference. (Omiya, Japan, November 20-23, 1998).

Ghabanchi, Z. and Meidani, E.N. (2012). "Beliefs about language learning and strategy use: the case of Iranian non-English majors", in World Journal of English Language, 2 (1): 21-30.

Horwitz, E.K. (1987). "Surveying student beliefs about language leaming”, in A.L. Wenden and J. Rubin (eds.), Learner Strategies in Language Learning. Englewoods Cliffs, NY: Prentice Hall, 119-132.

Horwitz, E.K. (1999). "Cultural and situational influences on foreign language learners' beliefs about language learning: A review of BALLI studies", in System, 27 (4): 557-576.

Huang, S.C. and Tsai, R.R. (2003). "A comparison between high and low English proficiency learners' beliefs", in ERIC Document Reproduction Service No. ED 482579.

Kalaja P. and Ferreira, A.M (Eds.) (2003). Beliefs about SLA. New Research Approaches. The Netherlands: Kluwer Academic Publishers.

Kalaja, P. (2003). "Research on students' beliefs about SLA within a discursive approach", in P. Kalaja and A.M. Ferreira (eds.), Beliefs about SLA: New Research Approaches. Netherlands: Kluwer Academic Publishers, 131-152.

Kim-Yoon, H. (2000). Learner beliefs about language learning, motivation and their relationship: A study of EFL learners in Korea, Unpublished doctoral dissertation. The University of Texas at Austin, TX.

Kramsch, C. (2003). "Metaphor and the subjective construction of beliefs", in P. Kalaja and A.M. Ferreira (eds.), Beliefs about SLA: New research approaches. Dordrecht: Kluwer Academic Publishers, 109-128.

Kunt, N. (1998). "Anxiety and beliefs about language learning: A study of Turkish-speaking uni- 
versity students learning English in North Cyprus", Dissertation Abstracts International, A: The Humanities and Social Sciences 59(1), July

Kuntz, P. (1996). "Beliefs about Language Learning: The Horwitz Model", ERIC Document Reproduction Service, No. ED397649.

Larsen-Freeman, D. (2001). "Individual cognitive/affective learner contributions and differential success in second language acquisition", in M.P. Breen (ed.), Learner Contributions to Language Learning. Harlow, Essex: Pearson, 12-24.

Loewen, S. Li, Fei, F., Thompson, A., Nakatsukasa, K., Ahn, S. and Chen, X. (2009). "L2 learners' beliefs about grammar instruction and error correction", in Modern Language Journal, 93 (1): 91-104.

Maftoon, P. and Shakouri, N. (2013). "Relationship between learners' beliefs system and the choice of language learning strategies: A critical study", in International Journal of Research Studies in Language Learning, 2 (2): 39-48.

Mantle-Bromley, C. (1995). "Positive attitudes and realistic beliefs: Links to proficiency", in Modern Language Journal, 79: 372-386.

McDonough, S. (1995). Strategy and Skill in Learning a Foreign Language. London: Edward Arnold.

Mohammad, S. and Shokrpour, N. (2012). "The beliefs of Iranian ESP students about language learning", in Journal of Educational and Social Research, 2 (3): 157-163.

Mori, Y. (1999). "Epistemological beliefs and language learning beliefs: What do language learners believe about their learning?", in Language Learning, 49 (3): 377-415.

Nikitina, L. and Furuoka, F. (2007). "Beliefs about language learning: A comparison between novice and intermediate level students learning Russian at a Malaysian university", in The Linguistics Journal, 2(1): 7-27.

Park, G.P. (1995). Language learning strategies and beliefs about language learning of university students learning English in Korea. Unpublished Doctoral Dissertation, The University of Texas at Austin, USA.

Pazaver, A. and Wang, H. (2009). "Asian students' perceptions of grammar teaching in the ESL classroom", in The International Journal of Language, Society and Culture, 27: 27-35.

Peackock, M. (1999). "Beliefs about language learning and their relationship to proficiency", in International Journal of Applied Linguistics, 9(2): 247-266.

Richards J.C. and Lockhart, C. (1994). Reflective Teaching in Second Language Classrooms. Cambridge: Cambridge University Press.

Rifkin, B. (2000). "Revising beliefs about foreign language learning", in Foreign Language Annals 33(4): 394-420.

Riley, P. (1997). “BATS' and 'BALLS': Beliefs about talk and beliefs about language learning”, in Mélanges CRAPEL, 23: 125-153.

Sakui, K. and Gaies, S.J. (1999). "Investigating Japanese learners' beliefs about language learning", in System, 27: 473-492.

Saleh, A. (2012). "Assessing Saudi learners' beliefs about English language learning", in International Journal of English and Education, 1 (2): 31-55.

Siebert, L. (2003). "Student and teacher beliefs about language learning", in Foreign Language Annals, 33(4): 394-420

Tanaka, K. (2004). Changes in Japanese students' beliefs about language learning and English language proficiency in a study-abroad context. Unpublished $\mathrm{PhD}$ thesis, University of Auckland. 
Tanaka, K. and Ellis, R. (2003). "Study-abroad, language proficiency and learner beliefs about language learning", in JALT Journal, 25(1): 63-85.

Victori, M. and Lockhart, W. (1995). "Enhancing metacognition in self-directed language learning", in System, 23(2): 223-234.

Victori, M. (1999). "Methodological issues in research on learners beliefs about language learning". Paper presented at the meeting of the 12th World Congress of Applied Linguistics (AILA 1999), Tokyo: Japan.

Wenden, A. (1999). "An introduction to metacognitive knowledge and beliefs in language learning: Beyond the basics [Special Issue]", in System, 27: 435-441.

White, C. (1999). "Expectations and emergent beliefs of self-instructed language learners", in System, 27(4): 443-457.

Williams, M. and Burden, R.L. (1997). Psychology for Language Teachers: A Social Constructivist Approach. Cambridge: Cambridge University Press.

Williams, M., Burden, R., Poulet, G. and Maun, I. (2004). "Learners' perceptions of their successes and failures in foreign language learning", in Language Learning Journal, 30: 19-29.

Woods, D. (2003). "The social construction of beliefs in the language classroom", in P. Kalaja and A.M. Ferreira (eds.), Beliefs about SLA: New Research Approaches. Dordrecht: Kluwer Academic Publishers, 201-229.

Yang, N.D. (1999). “The relationship between EFL learners' beliefs and learning strategy Use", in System, 27: 515-535.

Yoshida, R. (2013). "Conflict between learners' beliefs and actions: Speaking in the classroom", in Language Awareness, DOI:10.1080/0009658416.2012.758129

Zhong, M. (2008). "Report of a pilot study of the beliefs of one migrant learner of English". Unpublished paper, Department of Applied language Studies and Linguistics, University of Auckland.

Zhong, Q. (2010). "The effect of Chinese ESL learners' beliefs on their autonomous learning", in Studies in Self-Access Learning Journal, 1 (3): 212-225. 